\title{
Allelic composition of puroindolinium genes and confectionery properties of flour of soft winter wheat samples
}

\author{
0. Yu. Leonov, Ya. Yu. Sharypina, Z. V. Usova, K. Yu. Suvorova, T. V. Sakhno \\ Plant Production Institute nd. a. V. Ya. Yuriev, NAAS of Ukraine, 142 Moskovskyi ave., Kharkiv, 61060, Ukraine, \\ e-mail:yuriev1908@gmail.com
}

Purpose. Identification of soft winter wheat varieties and lines from the Plant Production Institute nd. a. V. Ya. Yuryev, NAAS by allelic state of Pina-D1 and Pinb-D1 genes for targeted use in the breeding for high confectionery properties of flour. Methods. Identification of the Pina-D1 and Pinb-D1 genes allelic state was performed by polymerase chain reaction (PCR) using allele-specific primer pairs. Confectionery properties of flour were evaluated by determining the quality indicators: the water absorption capacity (WAC) of the flour, trial baking of cookies and evaluation of its quality. Results. According to the results of PCR analysis, 9 samples had an allelic composition of puroindoline genes (Pina-D1a and Pinb-D1a) characteristic for soft-grained varieties. Flour of the lines 'L137-26-0-2', 'L137-26-0-3' had the best confectionery properties, it had a WAC value less than $55 \%$, cookies diameter $85 \mathrm{~mm}$, cookies height $10 \mathrm{~mm}$, estimation of a surface of cookies 7-9 points, what meets the requirements for soft-grained wheat. $76 \%$ of the samples belonged to hard-grained varieties and had the corresponding alleles of the Pina-D1 or Pinb-D1 genes. In the studied sample, Pina-D1 gene is represented by 2 alleles: Pina-D1a and Pina-D1b. 27 samples had Pina-D1a allele, which also allows them to be used in breeding programs for grain quality when crossed with soft samples, 4 ones had Pina-D1b allele. As to Pinb-D1 gene, all hard grain samples had Pinb-D1b allele, and the 'Erythrospermum S 424-1/14' line was heterogeneous for Pinb-D1a/Pinb-D1b. The flour of these samples had typical for hard wheat quality indicators: WAC $68 \%$ and more, cookie diameter of $60-72 \mathrm{~mm}$, cookie height of 13-15 mm, the surface evaluation of 1-4 points. Conclusions. The studies allowed to differentiate the breeding material and transfer a soft winter wheat cultivar of a confectionery use 'L137-26-0-3' ('Mazurok') which has an allelic structure of puroindolins genes (Pina-D1a and Pinb-D1a) characteristic for soft-grained varieties and high confectionery flour properties for qualification examination.

Keywords: common winter wheat; variety; line; Pina and Pinb genes; water absorption capacity; cookies.

\section{Introduction}

Winter wheat (Triticum aestivum L.) is the leading grain crop in Ukraine; it surpasses other grain crops in terms of sown areas (5.9-6.5 million hectares) and forms the basis for the formation of the country's grain balance [1]. In the context of a market economy, increased competition in the market and in connection with Ukraine's entry into the World Trade Organization, increasing the competitiveness of agricultural products becomes especially relevant.

Special attention should be paid to improving the competitiveness of grain products, including increasing its technical and quality level $[2,3]$. At the same time, consumer re-

Oleh Leonov

https://orcid.org/0000-0001-9191-8658

Yaroslava Sharypina

https://orcid.org/0000-0001-5078-1608

Zoya Usova

https://orcid.org/0000-0002-0306-5809

Kateryna Suvorova

https://orcid.org/0000-0001-6658-1272

Tamara Sakhno

https://orcid.org/0000-0002-1740-4330 quirements for food and baking properties are growing and expanding, in particular, the creation of confectionery varieties necessary for manufacture of cakes and pastries is urgent [4].

Commodity classifications of grain in some EU countries are based on the peculiarities of the endosperm structure, in Ukraine this indicator is not taken into account [5-8]. The world is successfully breeding wheat varieties for special purposes. Soft wheat varieties 'Ami', 'MV Irma', 'Webster', 'Wisdom', 'FS 401' and others have been created among them. However, due to the low level of adaptability to growing conditions, they are not introduced on the territory of Ukraine [9]. Only two varieties of soft-grain wheat - 'Biliava' (Plant Breeding and Genetics Institute - National Center for Seed Production and Variety Research, UA) and 'Arkeoks' (Limagrain Europe, FR), which have the indices necessary for confectionery wheat have been entered into the State Register of Plant Varieties of Ukraine by 2020 [10].

The grain hardness of soft wheat is one of the most important characteristics of grain quality and directly related to grain grinding, dough kneading and making bakery products. Depending on the manifestation of this trait, wheat 
grain can be classified as a bakery or confectionery type [11]. Compared with soft endosperm caryopses, in varieties with a hard endosperm, grain grinding is a long and energy-intensive process. As a result, flour with large particles is formed. It contains a large amount of damaged starch grains, due to which it has a high water absorption capacity (WAC, \%). Due to the availability of a large amount of carbohydrates as a substrate for yeast, such flour is better for yeast bread baking [12]. High-quality confectionery products are made from special types of flour, obtained when grinding grain of specific soft-grain wheat varieties. Confectionery wheat flour differs significantly in its technological properties from baking wheat flour. This flour has a characteristic consistency; it is looser than baker's and has a low specific gravity, significantly lower WAC compared to baking flour. Such technological characteristics of the flour provide a high thermoplasticity of the pastry kneadind in the first minutes of baking, due to which obtained biscuits are more loose and of better quality both in terms of organoleptic, taste, and biological characteristics of the nutritional value of the product [4]. Studies of the nature of endosperm structure inheritance revealed that the differences in cultivars in this trait are determined by several linked genes located on the short arm of chromosome $5 \mathrm{D}$ at the B locus (Hardness) [13, 14].

The genes encode three polypeptides that form the freeabilin protein: puroindoline a (Pina-D1 gene), puroindoline b (Pinb-D1 gene), and Grain Softness Protein (Gsp-1 gene). Changes in the amino acid composition of these polypeptides are closely related to changes in grain texture. Soft wheat varieties contain both "wild" alleles of Pina-D1 gene (Pina-D1a allele) and the Pinb gene (Pinb-D1a allele), while hard-grain wheat varieties contain either a deletion of the Pina-D1 gene, or one of the "mutant" forms of Pinb-D1 gene (alleles PinbD1b-g or Pinb-D1l) [15-17].

Considering the prospect of breeding directions expanding in order to increase the competitiveness of soft winter wheat varieties, the corresponding studies (the search and attraction of new source material for soft wheat breeding) are carried out at Plant Production Institute nd. a. V. Ya. Yuriev, NAAS of Ukraine. Since 2001, varieties and lines with high adaptive potential have been crossed with soft-grain varieties and lines of foreign breeding. At the National Center for Plant Genetic Resources of Ukraine, soft-grain lines [18-20] were registered, as well as an indicative collection of confectionery properties [21], a number of constant selection lines of confectionery use were created, which are now being pre-tested, and the variety of soft-grain wheat 'Mazurok' was transferred to qualification examination at the Ukrainian Institute for Plant Varieties Examination.

The effective use of foreign material during hybridization with high-yielding local varieties adapted to the conditions of Ukraine is possible when the latter are identified by the allelic state of puroindolinium genes. Today, the allelic composition of these genes is being actively studied in varieties created at the Plant Breeding and Genetics Institute - National Center for Seed Production and Variety Research, the V. M. Remeslo Myronivka Institute of Weat, and Poltava State Agrarian Academy [23, 24].

The aim of the research is to identify Pina-D1 and Pinb-D1 genes of soft winter wheat samples of the Plant Production Institute nd. a. V. Ya. Yuriev, NAAS of Ukraine for further use in breeding for high confectionery properties of flour.

\section{Materials and methods}

Grains of 25 varieties of winter wheat, 12 selection lines of confectionery direction of use, which are pre-tested, 3 lines of Triticum spelta L were used in the study. As the standards of technological parameters of flour, we used the soft-grain variety 'Biliava' and the hard-grain variety 'Pryvablyva'.

Preliminary selection of soft-grain forms was carried out by determining the indicators: WAC of flour, test baking and evaluation of the quality of cookies [22].

To identify the allelic states of Pina-D1 and Pinb-D1 genes in the soft winter wheat samples, the polymerase chain reaction (PCR) method was used with the use of target gene markers.

DNA isolation was carried out from 5 grains of ten individual plants of each sample using the DiatomDNAPrep100 reagent kit (Neogen). DNA amplification was performed in tubes with a lyophilized PCR reagent kit (GenePak PCR core) in a Tertsik amplifier (Russia).

The reaction mixture for PCR analysis, which contained $20 \mathrm{ng}$ of isolated DNA, $1 \mu \mathrm{M}$ of forward and reverse primers, was brought to the final volume $(20 \mu \mathrm{l})$ with the solvent from the PCR kit.

The identification of the allelic state of Pina D1 and Pinb-D1 genes was carried out using primers proposed by Gautier et al. [25] and Klčová et al. [26]. Differentiation of Pinb-D1 alleles (pinb-D1a and pinb-D1b) was performed with allele-specific primer pairs [27] and restriction analysis proposed by Klčová et al. [26] (Table 1). 
Primers for identification of Pina-D1 and Pinb-D1 gene alleles

\begin{tabular}{|c|c|l|l|}
\hline Gene & Fragment length & Primer name & \multicolumn{1}{|c|}{ Sequence } \\
\hline Pina-D1 & 330 & $\begin{array}{l}\text { Pina-D1-F } \\
\text { Pina-D1-R }\end{array}$ & $\begin{array}{l}\text { CCC TGT AGA GAC AAA GCT AA } \\
\text { TCA CCA GTA ATA GCC AAT AGT G }\end{array}$ \\
\hline \multirow{3}{*}{ Pinb-D1 } & 447 & $\begin{array}{l}\text { Pinb-D1-F } \\
\text { Pinb-D1-R }\end{array}$ & $\begin{array}{l}\text { ATG AAG ACC TTA TTC CTC CTA } \\
\text { TCA CCA GTA ATA GCC ACT AGG GAA }\end{array}$ \\
\cline { 2 - 4 } & 250 & $\begin{array}{l}\text { Pinb-glyR } \\
\text { Pinb-serR }\end{array}$ & $\begin{array}{l}\text { CTC ATG CTC ACA GCC GCC } \\
\text { CTC ATG CTC ACA GCC GCT }\end{array}$ \\
\hline
\end{tabular}

For identification, we used winter wheat varieties with known alleles of Pina-D1 and Pinb-D1 genes: 'Rheia' - Pin a D1b, 'Vasylyna' - Pin a D1a, Pin $b$ D1 $b$, serine, 'Mirleben' - Pin a D1a, Pin $b$ D1a, glycine [23, 25].

Amplification for all pairs of primers was performed under the following conditions: denaturation $95 \mathrm{eC}(5 \mathrm{~min})$, then 35 cycles: $94{ }^{\circ} \mathrm{C}$ (30 sec), $60{ }^{\circ} \mathrm{C}(30 \mathrm{sec}), 72{ }^{\circ} \mathrm{C}(1 \mathrm{~min} 15 \mathrm{sec})$, final elongation $72{ }^{\circ} \mathrm{C}(7 \mathrm{~min})$.

Amplification products were visualized by electrophoresis in $2.0 \%$ agarose gel in borate buffer; ethidium bromide was used for DNA monitoring in ultraviolet light according to the standard procedure [28]. Electrophoresis was performed in a horizontal Hoefer SuperSub100 device. M 50 GENPAK $^{\circledR}$ was used as a molecular weight marker. The resulting gels were documented using Nikon D50 camera.

To determine the size of the amplification products, a demo version of the TotalLab 120 program (http://www.totallab.com) was used.

\section{Results and discussion}

Varieties and new breeding lines of winter wheat were preliminarily differentiated by confectionery properties, having determined technological indicators of confectionery quali-

Confectionery properties of soft winter wheat samples (2016-2019)

\begin{tabular}{|c|c|c|c|c|c|}
\hline \multirow{2}{*}{ Sample name } & \multicolumn{4}{|c|}{ Evaluation of cookies } & \multirow{2}{*}{$\begin{array}{c}\text { WAC, } \\
\%\end{array}$} \\
\hline & diameter (D), $\mathrm{mm}$ & thickness (T), mm & $\mathrm{D} / \mathrm{T}$ & evaluation of the cookie surface, score & \\
\hline ‘Pryvablyva’ - St & 79.17 & 12.27 & 6.48 & 4 & 62.7 \\
\hline ‘Metelytsia kharkivska' & 80.48 & 11.13 & 7.27 & 6 & 62.2 \\
\hline ‘Erytrospermum 533-16’ & 82.17 & 10.82 & 7.64 & 7 & 65.3 \\
\hline ‘Liutestsens 652-16’ & 73.67 & 12,13 & 6.09 & 7 & 68.4 \\
\hline ‘L 139-03 KH’ & 81.57 & 11.00 & 7.50 & 7 & 62.7 \\
\hline ‘Erytrospermum S 424-1/14' & 80.00 & 11.14 & 7.28 & 6 & 59.1 \\
\hline ‘Erytrospermum 1002-16’ & 77.67 & 11.57 & 6.73 & 7 & 66.1 \\
\hline ‘Erytrospermum 1003-16’ & 80.33 & 11.07 & 7.26 & 7 & 61.0 \\
\hline ‘L137-26-0-2' & 85.10 & 10.07 & 8.61 & 8 & 52.7 \\
\hline ‘L137-26-0-3’ & 86.00 & 9.95 & 8.68 & 9 & 53.1 \\
\hline ‘L202-20’ & 80.04 & 11.32 & 7.20 & 6 & 56.8 \\
\hline 'S 492-3/14' & 77.00 & 11.27 & 6.83 & 9 & 62.3 \\
\hline 'VS 2019-1/15' & 76.67 & 12.03 & 6.37 & 7 & 65.8 \\
\hline 'VS 497-2/14' & 77.33 & 11.50 & 6.73 & 7 & 68.4 \\
\hline 'T. spelta $1139-16$ ' & 77.33 & 12.77 & 6.06 & 4 & 71.8 \\
\hline 'T. spelta 1140-16' & 74.67 & 12.30 & 6.07 & 3 & 68.8 \\
\hline 'T. spelta $1145-16^{\prime}$ & 76.67 & 11.97 & 6.41 & 1 & 69.0 \\
\hline ‘Doridna' & 77.33 & 11.73 & 6.59 & 4 & 69.9 \\
\hline 'Pryvitna' & 78.67 & 12.07 & 6.52 & 4 & 72.4 \\
\hline 'Prynada' & 83.33 & 12.03 & 6.93 & 3 & 68.5 \\
\hline 'Vyhadka' & 76.67 & 12.43 & 6.17 & 4 & 66.3 \\
\hline 'Fermerka' & 74.67 & 12.83 & 5.82 & 4 & 68.3 \\
\hline ‘Pronia' & 77.67 & 12.23 & 6.35 & 4 & 65.9 \\
\hline ‘Doskonala' & 77.33 & 12.37 & 6.25 & 4 & 66.6 \\
\hline ‘Rozkishna' & 77.33 & 11.93 & 6.48 & 3 & 71.0 \\
\hline 'Alians' & 76.00 & 11.63 & 6.53 & 4 & 64.3 \\
\hline 'Zdobna' & 76.67 & 11.53 & 6.65 & 3 & 71.9 \\
\hline ‘Harmonika' & 77.33 & 12.20 & 6.34 & 4 & 72.7 \\
\hline 'Krasa laniv' & 79.67 & 12.20 & 6.53 & 4 & 73.3 \\
\hline ‘Patriotka' & 77.00 & 12.43 & 6.19 & 4 & 74.1 \\
\hline 'Zapashna' & 77.45 & 11.58 & 6.70 & 4 & 67.6 \\
\hline 'Biliava' - St & 86.70 & 10.10 & 8.60 & 6 & 54.6 \\
\hline
\end{tabular}


ty: flour WAC, test baking and evaluation of the quality of cookies [22] (Table 2). The research results indicate that the quality of confectionery products varied significantly depending on the sample.

It is known that the larger the diameter of the biscuit and the smaller the thickness, the higher its quality [22]. The greatest ratio of the diameter of the biscuit to its thickness was obtained for wheat flour of the lines 'L137-26-0-3' - 8.68, 'L137-26-0-2' - 8.61, at the standard level soft-grain varieties 'Biliava' and significantly higher in comparison with the standard hard grain variety 'Pryvablyva' - 6.48. These samples were characterized by low SPO rates of $53.1 \%$ and $52.7 \%$, respectively. Hard-grain winter wheat varieties 'Fermerka', 'Doskonala', 'Rozkishna', 'Alians' , 'Zdobna', 'Harmonika', 'Krasa laniv', 'Patriotka' and a number of lines had a low ratio of cookie diameter to its thickness $(5,82-6.82)$ and, accordingly, high WAC rates of $65.9-74.1 \%$. Lines T. spelta by confectionery parameters of flour are attributed to hard grain samples. Allelic state of genes Pina$D 1$ and Pinb-D1 of 40 varieties and winter wheat lines was determined (Table 3).

As a result of the study using allele-specific primers, the presence of a $330 \mathrm{bp}$ fragment, that corresponds to the Pina-D1a allele of the puroindoline $a$ gene [26], was revealed in 36 wheat samples. The absence of the amplification product on the electrophoregram corre-

Table 3

Allelic state of $P$ in $\boldsymbol{a}$ and $P$ in $\boldsymbol{b}$ genes of soft winter wheat samples

\begin{tabular}{|c|c|c|c|c|}
\hline № & Sample name & Pina-D1 allele & Pinb-D1 allele & Amino acid \\
\hline 1 & ‘Pryvablyva' & Pina-D1a & Pinb-D1b & serine \\
\hline 2 & ‘Metelytsia' & Pina-D1b & Pinb-D1b & serine \\
\hline 3 & ‘Erytrospermum 533-16’ & Pina-D1b & Pinb-D1b & serine \\
\hline 4 & 'Lyutestsens 652-16’ & Pina-D1b & Pinb-D1b & serine \\
\hline 5 & ‘L 139-03 KH’ & Pina-D1a & Pinb-D1a & glycine \\
\hline 6 & “Erytrospermum S 424-1/14' & Pina-D1a & $\begin{array}{l}\text { Pinb-D1a } \\
\text { Pinb-D1b }\end{array}$ & $\begin{array}{l}\text { glycine } \\
\text { serine }\end{array}$ \\
\hline 7 & 'Erytrospermum 1002-16' & Pina-D1a & Pinb-D1a & glycine \\
\hline 8 & ‘Erytrospermum 1003-16’ & Pina-D1a & Pinb-D1a & glycine \\
\hline 9 & ‘L137-26-0-2' & Pina-D1a & Pinb-D1a & glycine \\
\hline 10 & ‘L137-26-0-3’ & Pina-D1a & Pinb-D1a & glycine \\
\hline 11 & ‘L202-20’ & Pina-D1a & Pinb-D1a & glycine \\
\hline 12 & 'S 492-3/14' & Pina-D1a & Pinb-D1a & glycine \\
\hline 13 & 'VS 2019-1/15' & Pina-D1a & Pinb-D1a & glycine \\
\hline 14 & 'VS 497-2/14' & Pina-D1a & Pinb-D1a & glycine \\
\hline 15 & 'T. spelta $1139-16$ ' & Pina-D1a & Pinb-D1b & serine \\
\hline 16 & 'T. spelta 1140-16’ & Pina-D1a & Pinb-D1b & serine \\
\hline 17 & ‘T. spelta $1145-16 ’$ & Pina-D1a & Pinb-D1b & serine \\
\hline 18 & ‘Doridna' & Pina-D1a & Pinb-D1b & serine \\
\hline 19 & ‘Pryvitna' & Pina-D1a & Pinb-D1b & serine \\
\hline 20 & ‘Prynada' & Pina-D1a & Pinb-D1b & serine \\
\hline 21 & 'Vyhadka' & Pina-D1a & Pinb-D1b & serine \\
\hline 22 & ‘Fermerka' & Pina-D1a & Pinb-D1b & serine \\
\hline 23 & ‘Pronia’ & Pina-D1a & Pinb-D1b & serine \\
\hline 24 & ‘Doskonala’ & Pina-D1a & Pinb-D1b & serine \\
\hline 25 & ‘Rozkishna' & Pina-D1a & Pinb-D1b & serine \\
\hline 26 & 'Korovayna' & Pina-D1a & Pinb-D1b & serine \\
\hline 27 & ‘Al yans' & Pina-D1a & Pinb-D1b & serine \\
\hline 28 & 'Vasylyna' - St & Pina-D1a & Pinb-D1b & serine \\
\hline 29 & 'Astet' & Pina-D1a & Pinb-D1b & serine \\
\hline 30 & 'Zdobna' & Pina-D1a & Pinb-D1b & serine \\
\hline 31 & ‘Harmonika' & Pina-D1a & Pinb-D1b & serine \\
\hline 32 & 'Krasa laniv' & Pina-D1a & Pinb-D1b & serine \\
\hline 33 & ‘Patriotka’ & Pina-D1a & Pinb-D1b & serine \\
\hline 34 & ‘Hayok' & Pina-D1a & Pinb-D1b & serine \\
\hline 35 & 'Statna' & Pina-D1a & Pinb-D1b & serine \\
\hline 36 & 'Zapashna' & Pina-D1a & Pinb-D1b & serine \\
\hline 37 & ‘Dyvo' & Pina-D1a & Pinb-D1b & serine \\
\hline 38 & ‘Bona Dea' & Pina-D1a & Pinb-D1b & serine \\
\hline 39 & ‘Rheia' - St & Pina-D1b & - & - \\
\hline 40 & ‘Myrleben' - St & Pina-D1a & Pinb-D1a & glycine \\
\hline
\end{tabular}


sponds to Pina-D1b allele, which was identified 'Erythrospermum 533-16', 'Liutescens 652-16' in the samples of 'Metelytsia kharkivska', (Fig. 1).

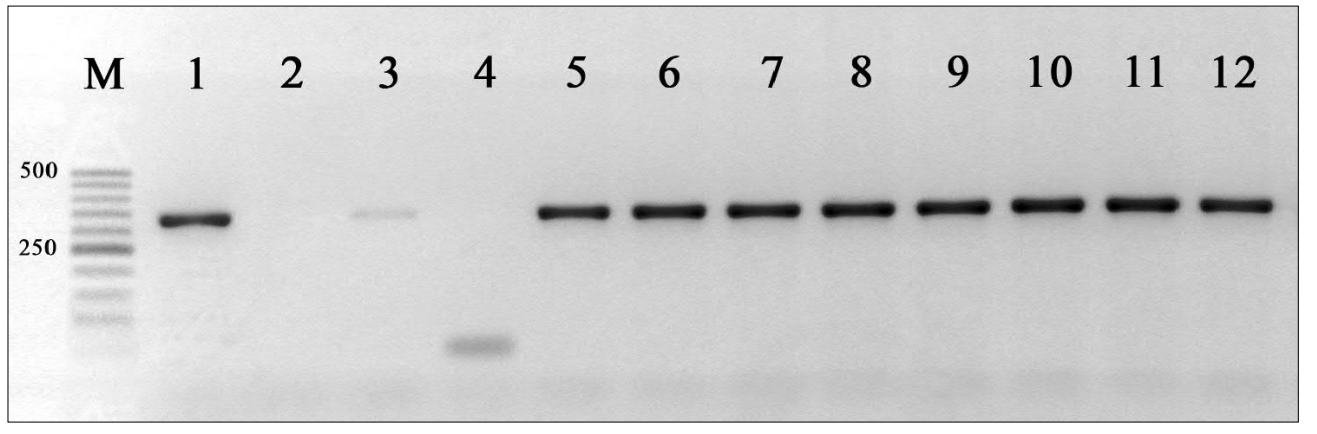

Fig. 1. Electrophoregram of PCR products with specific primers for Pina D1 gene:

M - molecular weight marker M 50 GENPAK ${ }^{\circledR} ; 1$ - 'Pryvablyva', 2 - 'Metelytsia Kharkivska',

3 - 'Erythrospermum 533-16', 4 - 'Lutescens 652-16', 5 - 'L 139-03 KN', 6 - 'Erythrospermum S 424- 1/14',

7 - 'Erythrospermum 1002-16', 8 - 'Erythrospermum 1003-16', 9 - 'L137-26-0-2', 10 - 'L137-26-0-3', 11 - 'L202-20', 12 - 'S 492-3/14'

As a result of the allelic state of the puroindoline $b$ gene in the lines 'L139-03 KH', 'L137-26-0-2', 'L137-26-0-3' and others (Fig. 2), the presence of glycine at position 46 of the polypeptide was determined, as evidenced by the amplification products of $250 \mathrm{bp}$.

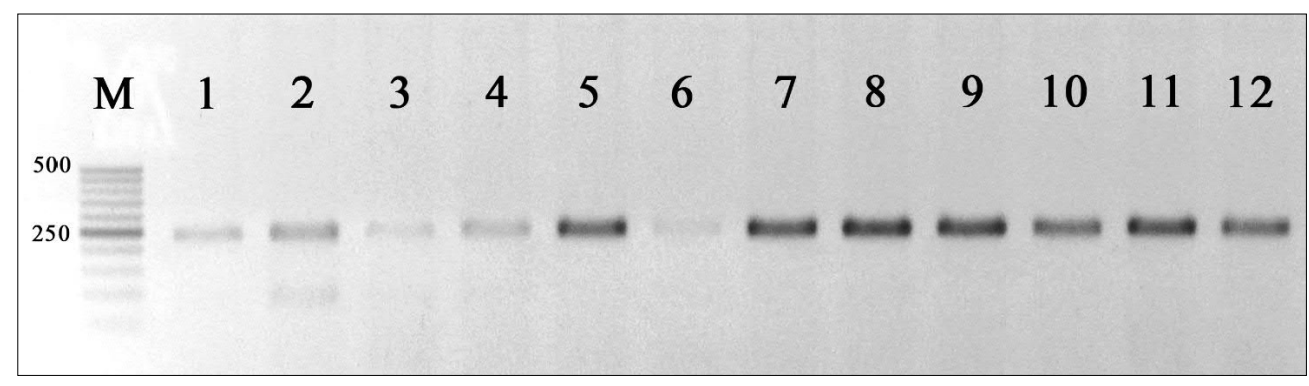

Fig. 2. Electropherogram of PCR products with primers to Pinb-D1 alleles (see description to Fig. 1)

It is known that, despite the difference in allele-specific primer pairs by only one nucleotide, there is a possibility of errors in the determination of Pinb-D1 alleles using primers to the glycine nucleotide sequence [27]. So, when carrying out PCR with primers that determine serine at position 46 of the pin- $b$ protein, the amplification product of $250 \mathrm{bp}$ in size was obtained in all studied varieties. Therefore, to obtain reliable information about the allelic state of Pinb-D1 in the study, an analysis was performed using the restriction endonuclease MbiI (BsrBI). Amplification was carried out using primers to Pinb-D1 gene designed by Giroux et al. [25]; an amplification product of $447 \mathrm{bp}$ was obtained, which was further cleaved with endonuclease. The enzyme recognizes the CCGICTC nucleotide sequence, which determines the change from glycine to serine. After incubation with restriction endonuclease amplification products $447 \mathrm{bp}$ in the absence of mutation on the electrophoretogram,

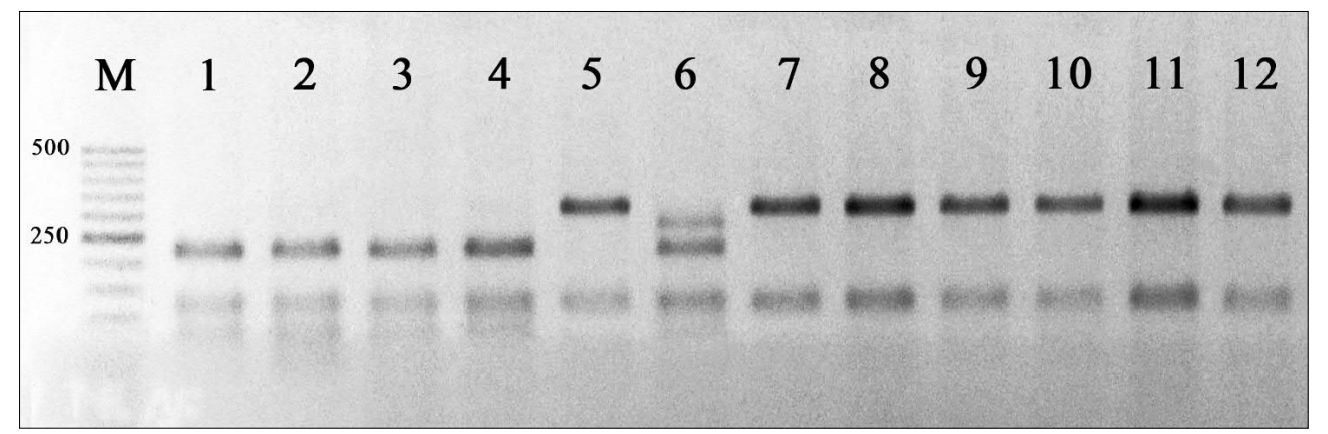

Fig. 3. Electropherogram of $P C R$ products with primers to the nucleotide sequence of serine in determination of Pinb-D1 alleles (see description to Fig. 1) 
amplicons of 320 bp were observed. In genotypes where, as a result of the mutation, glycine was replaced by serine, the amplicons were 200 bp (Fig. 3).

The analysis revealed the presence of serine at position 46 of the puroindoline b protein in 30 out of 40 samples.

According to the results of PCR analysis of the allelic composition of puroindolinium genes out of a total of 37 samples, $9(24 \%)$ - had the allelic composition of the puroindolinium genes characteristic for soft-grain varieties, PinaD1a and Pinb-D1a ('L139-03KH', 'L137-26-0-2', 'L137-26-0-3', 'L202-20', 'Erythrospermum 1002-16', 'Erythrospermum 1003-16', 'S 492 $3 / 14$ ', 'VS 2019-1/15', 'VS 497-2/14'). soft winter wheat varieties 'MV Homber' (HUN), 'Warwik', 'Webster' (CAN), 'Eva' (SVK), 'FS 401' (USA), 'Oksana', 'Blond' (UKR) were used for these lines creating. The best confectionery indicators among soft-grain samples were in the lines 'L137-26-0-2', 'L137-26-0-3', which had WAC of less than $55 \%$, biscuit diameter $-85 \mathrm{~mm}$, height $-10 \mathrm{~mm}$, surface assessment cookies 8-9 points. The remaining 7 lines were characterized as satisfactory by the confectionery properties of flour.

$76 \%$ of the samples had the alleles of PinaD1 and Pinb-D1 genes, which are typical for hard-grain varieties. In the studied selection of hard-grain samples, the Pina-D1 gene is represented by two alleles: Pina-D1a and Pina-D1b. 27 samples of winter wheat had Pina-D1a allele, which allows to use them in breeding for softgrain quality when crossed with soft samples, 3 samples had Pina-D1b allele ('Metelytsia Kharkivska', 'Erythrospermum 533-16', 'Liutescens 652-16'). All hard-grain samples had Pin$b D 1 b$ allele in Pinb-D1 gene, and the 'Erythrospermum S 424-1/14' line was heterogeneous. These samples had quality indicators characteristic of hard-grain wheat: WAC $-68 \%$ and above, diameter - 60-72 $\mathrm{mm}$, biscuit height 13-15 mm, surface score $-1-4$ points.

T. spelta lines, involved in the analysis, both for alleles of puroindolinium genes and for the technological confectionery properties of flour, were included in the group of hard-grain samples.

\section{Conclusions}

The allelic state of PINa-D1 and Pinb-D1 genes was revealed for 37 varieties and lines of soft winter wheat breeding of Plant Production Institute nd. a. V. Ya. Yuriev NAAS.

Lines 'L139-03KH', 'L137-26-0-2', 'L137-26-0-3', 'L202-20', 'Erythrospermum 1002-16', 'Erythrospermum 1003-16', S' 492-3/14', 'VS 2019-1/15', 'VS 497-2/14' had an allelic state of the puroin- dolinium genes characteristic for soft-grain varieties (Pina-D1a, Pinb-D1a), good and satisfactory confectionery indicators of flour quality.

$76 \%$ of the studied cultivars had the allelic composition of puroindoliniums Pina-D1a/ Pina-D1b; Pinb-D1b, i.e. were characterized as hard-grain samples of Triticum aestivum $\mathrm{L}$.

The studies allowed to differentiate the created linear material and transfer for the qualification examination the soft winter wheat variety of confectionery use 'L137-26-0-3' ('Mazurok') with a genetically confirmed soft-grain structure of endosperm and high confectionery properties of flour; transfer the lines of winter wheat with high confectionery properties for registration to the NCPGRU.

'Mazurok' ('L 137-26-0-3') is a soft-grain variety of winter wheat for confectionery use. The variety is high-yielding (7.93 t/ha), highly resistant to damage by leaf septoria (7 points), powdery mildew (7 points); its frost resistance is 7 points. According to technological indicators, it is referred to soft red winter wheat, and has increased confectionery properties: low protein content in grain - $11 \%$, vitreousness $-25 \%$, flour strength -73 w. i., WAC $53 \%$, high biscuit linear dimensions, $\mathrm{D} / \mathrm{T}$ ratio, high biscuit surface score -9 points.

\section{References}

1. Danylenko, V., Kovalenko, M., \& Salashna, V. (2019). The current state of crop production in Ukraine. Derzhava ta rehiony. Ser.: Ekonomika ta pidpryiemnytstvo [State and regions. Ser.: Economics and Business], 4, 93-98. doi: 10.32840/18141161/2019-4-16 [in Ukrainian]

2. Patyka, N., \& Prib, K. (2019). Crop products world market and Ukraine's positions on it. Problemy systemnoho pidkhodu v ekonomitsi [Problems of Systemic Approach in the Economy], 1, 107-104. doi: 10.32782/2520-2200/2019-1-16 [in Ukrainian]

3. Liahovska, 0. V. (2019). Trends export of grain and its products in Ukraine. Derzhava ta rehiony. Ser.: Ekonomika ta pidpryiemnytstvo [State and regions. Ser.: Economics and Business], 5, 44-48. doi: 10.32840/1814-1161/2019-5-8 [in Ukrainian]

4. Rybalka, 0. I., Morgun, V. V., Morgun, B. V., \& Polishchuk, S. S. (2019). Genetic background for breeding of new quality classes of wheat (Triticum aestivum L.) and triticale ( $\times$ Triticosecale Wittmack). Fiziol. Rast. Genet. [Plant Physiology and Genetics], 51(3), 207-240. doi: 10.15407/frg2019.03.207 [in Ukrainian]

5. Ransom, J. (2015). Hard white wheat: producing North Dakota's next market opportunities., Fargo, ND: North Dakota State University. Retrieved from https://www.ag.ndsu.edu/publications/crops/hard-white-wheat-producing-north-dakotasnext-market-opportunity/a1310.pdf

6. Nandy, S., Chen, Q., Sun, Sh., Ahmad, F., Graf, R., \& Kreliuk, G. (2008). Nutrition alanalyses and their inheritance properties in colored wheat seed lines from different origins using near-infrared spectroscopy. Amer. J. Plant Sci. Biotechnol., 2(2), 74-79.

7. Hlupak, Z. I. (2019). Standardization and certification of grain in Ukraine and the European Union countries. Naukovi horyzonty [Scientific Horizons], 7, 63-69. doi: 10.33249/26632144-2019-80-7-63-69 [in Ukrainian]

8. Pshenytsia. Tekhnichni umovy: DSTU 3768:2019 [Wheat. Specifications: State Standart 3768:2019]. (2019). Kyiv: DP “Ukr NDNTs". [in Ukrainian] 
9. Yarosh, A. V., Ryabchun, V. K., Leonov, O. Yu., Didenko, S. Yu., \& Kopytina, LP. (2015). Source material for the creation of soft grain types of winter bread wheat with valuable economic traits. Henetychni resursy roslyn [Plant Genetic Resources], 16, 31-42 [in Ukrainian]

10. Derzhavnyi reiestr sortiv, prydatnykh dlia poshurennia $v$ Ukraini na $2020 \mathrm{r}$. [State register of plant varieties suitable for dissemination in Ukraine in 2020]. (2020). Retrieved from http:// sops.gov.ua/reestr-sortiv-roslin [in Ukrainian]

11. Pasha, I., Anjum, F. M., \& Morris, C. F. (2010). Grain hardness: a major determinant of wheat quality. Food Sci Tech Int., 16(6), 511-522. doi: 10.1177/1082013210379691

12. Mohammadi, M., Mehrazar, E., Izadi-Darbandi, A., \& Najafian, G. (2013). Genotype Diversity of Puroindoline Genes (Pina-D1 and Pinb-D1) in Bread Wheat Cultivars Developed in Iran and CIMMYT. J. Crop Improv., 27(4), 361-375. doi: $10.1080 / 15427528.2013 .775988$

13. Bhave, M., \& Morris, C. F. (2008). Molecular genetics of puroindolines and related genes: allelic diversity in wheat and other grasses. Plant Mol. Biol., 66(3), 205-219. doi: 10.1007/s11103007-9263-7

14. Morris, C. F. (2002). Puroindolines: the molecular genetic basis of wheat grain hardness. Plant Mol. Biol., 48(5-6), 633-647. doi: $10.1023 / a: 1014837431178$

15. Giroux, M. J., \& Morris, C. F. (1998). Wheat grain hardness results from highly conserved mutations in the friabilin components puroindoline a and b. Proc. Natl. Acad. Sci. U.S.A., 95(11), 6262-6266. doi: 10.1073/pnas.95.11.6262

16. Martin, J. M., Meyer, F. D., Smidansky, E. D., Wanjugi, H., Blechl, A. E., \& Giroux, M. J. (2006). Complementation of the pina (null) allele with the wild type pina sequence restores a soft phenotype in transgenic wheat. Theor. Appl. Genet. 113(8), 1563-1570. doi: 10.1007/s00122-006-0404-1

17. Mark, W., Wan, Y., Paola, T., Michelle, L., John, S., Rowanac, M., \& Peterr, S. (2008). Identification and genetic mapping of variant forms of puroindoline $b$ expressed in developing wheat grain. $J$. Cereal Sci., 48(3), 722-728. doi: 10.1016/j.plantsci.2008.05.006

18. Registration of plant gene pool accessions in Ukraine. (2016). Henetychni resursy roslyn [Plant Genetic Resources], 19, 138. [in Ukrainian]

19. Registration of plant gene pool accessions in Ukraine. (2017). Henetychni resursy roslyn [Plant Genetic Resources], 20, 113116. [in Ukrainian]

20. Registration of plant gene pool accessions in Ukraine. (2019). Henetychni resursy roslyn [Plant Genetic Resources], 24, 152. [in Ukrainian]

21. Registration of plant gene pool collections in Ukraine. (2017). Henetychni resursy roslyn [Plant Genetic Resources], 20, 133. [in Ukrainian]

22. Vasilenko, I. I., \& Komarov, V. I. (Eds.). (1987). Otsenka kachestva zerna [Assessment of grain quality]. Moscow: Agropromizdat. [in Russian]

23. Chebotar, S. V., Kurakina, K. 0., Khokhlov, 0. M., Chebotar, G. 0. \& Sivolap, Yu. M. (2012). Phenotypic effects of alleles of the common wheat puroindoline genes. Cytol Genet., 46(4), 202209. doi: $10.3103 /$ S0095452712040056

24. Chebotar, G. 0., Chebotar, S. V., Toporash ,M. K., Bakuma, A. 0. \&Tyshchenko, V. M. (2017). Characteristics of wheat varieties of Poltava State Agrarian Academy breeding with gene markers that determine important agronomical traits. Visn. ukr. tov. genet. sel. [The Bulletin of Vavilov Society of Geneticists and Breeders], 15(2), 187-195. doi: 10.7124/visnyk.utgis.15.2.878 [in Ukrainian]

25. Gautier, M. F., Aleman, M. E., \& Guirao, A. (1994). T. aestivum puroindolines, two basic cystine-rich seeds protein: cDNA sequence analysis and developmental gene expression. Plant Mol. Biol., 25(1), 43-57. doi 10.1007/BF00024197

26. Klčová, L., Mikulikova, D., Masar, Š., \& Žofajova, A. (2015). Evaluation of Slovak winter wheat quality in terms of puroindoline genes. Agriculture, (Polnohospodárstvo), 61(3), 88-96. doi: 10.1515/agri-2015-0014 [in Slovaká]
27. Giroux, M. J., \& Morris, C. F. (1997). A glycine to serine change in puroindoline $b$ is associated with wheat grain hardness and low levels of starch-surface friabilin. Theor. Appl. Genet., 95, 857-864. doi: 10.1007/s001220050636

28. Maniatis, T., Fritsch, E. F., \& Sambrook, J. (1984). Metody geneticheskoy inzhenerii. Molekulyarnoe klonirovanie. [Methods of genetic engineering. Molecular cloning]. Moscow: Mir. [in Russian]

\section{Використана література}

1. Даниленко В. І., Коваленко М. В., Салашна В. О. Сучасний стан виробництва продукції рослинництва в Україні. Держава та регіони. Сер.: Економіка та підприємництво. 2019. № 4. C. 93-98. doi: 10.32840/1814-1161/2019-4-16

2. Патика Н. І., Пріб К. А. Світовий ринок рослинницьких продуктів та позиції України на ньому. Проблеми системного підходу в економіці. 2019. № 1. С. 107-104. doi: 10.32782/2520-2200/2019-1-16

3. Ляховська 0. В. Тенденції експорту зерна і продуктів його переробки в Україні. Держава та регіони. Сер.: Економіка та підприємництво. 2019. № 5. С. 44-48. doi: 10.32840/1814$1161 / 2019-5-8$

4. Рибалка 0. І., Моргун В. В., Моргун Б. В., Поліщук С. С. Генетичні основи нового напряму селекції оригінальних за якістю зерна класів пшениці (Triticum aestivum L.) і тритикале (ЧTriticosecale Wittmack). Физиология раст. и генетика. 2019. T. 5, № 3. C. 207-240. doi: 10.15407/frg2019.03.207

5. Ransom J. Hard white wheat: producing North Dakota's next market opportunities. Fargo, ND : North Dakota State University, 2015. 8 p. URL: https://www.ag.ndsu.edu/publications/crops/ hard-white-wheat-producing-north-dakotas-next-marketopportunity/a1310.pdf

6. Nandy S., Chen Q., Sun S. C. et al. Nutritional analyses and their inheritance properties in colored wheat seed lines from different origins using near-infrared spectroscopy. Amer. J. Plant Sci. Biotechnol. 2008. Vol. 2, Iss. 2. P. 74-79.

7. Глупак 3. І. Стандартизація та сертифікація зерна в Україні та країнах Європейського союзу. Наукові горизонти. 2019. Т. 80 , № 7. C. 63-69. doi: 10.33249/2663-2144-2019-80-7-63-69

8. Пшениця. Технічні умови : ДСТУ 3768:2019. [Чинний від 201906-10]. Київ : ДП «Укр НДНЦ», 2019. 19 с.

9. Ярош А. В., Рябчун В. К., Леонов О. Ю. та ін. Вихідний матеріал для створення м'якозерних форм пшениці м'якої озимої. Генетичні ресурси рослин. 2015. № 16. С. 31-42.

10. Державний реєстр сортів рослин, придатних для поширення в Україні на 2020 рік. URL: https://sops.gov.ua/reestr-sortiv-roslin

11. Pasha I., Anjum F. M., Morris C. F. Grain hardness: a major determinant of wheat quality. Food Sci. Tech. Int. 2010. Vol. 16, Iss. 6. P. 511-522. doi: 10.1177/1082013210379691

12. Mohammadi M., Mehrazar E., Izadi-Darbandi A., Najafian G. Genotype Diversity of Puroindoline Genes (Pina-D1 and Pinb-D1) in Bread Wheat Cultivars Developed in Iran and CIMMYT. J. Crop Improv. 2013. Vol. 27, Iss. 4. P. 361-375. doi: $10.1080 / 15427528.2013 .775988$

13. Bhave M., Morris C. F. Molecular genetics of puroindolines and related genes: allelic diversity in wheat and other grasses. Plant Mol. Biol. 2008. Vol. 66, Iss. 3. P. 205-219. doi: 10.1007/ s11103-007-9263-7

14. Morris C. F. Puroindolines: the molecular genetic basis of wheat grain hardness. Plant Mol. Biol. 2002. Vol. 48, Iss. 5-6. P. 633647. doi: $10.1023 / a: 1014837431178$

15. Giroux M. J., Morris C. F. Wheat grain hardness results from highly conserved mutations in the friabilin components puroindoline a and b. Proc. Natl. Acad. Sci. U.S.A. 1998. Vol. 95, Iss. 11. P. 6262-6266. doi: 10.1073/pnas.95.11.6262

16. Martin J. M., Meyer F. D., Smidansky E. D. et al. Complementation of the pina (null) allele with the wild type pina sequence restores a soft phenotype in transgenic wheat. Theor. Appl. Genet. 2006. Vol. 113, Iss. 8. P. 1563-1570. doi: 10.1007/ s00122-006-0404-1 
17. Mark W., Wan Y., Paola T. et al. Identification and genetic mapping of variant forms of puroindoline $b$ expressed in developing wheat grain. J. Cereal Sci. 2008. Vol. 48, Iss. 3. P. 722-728. doi: 10.1016/j.plantsci.2008.05.006

18. Реєстрація зразків генофонду рослин в Україні. Генетичні ресурси рослин. 2016. № 19. С. 138.

19. Реєстрація зразків генофонду рослин в Україні. Генетичні ресурси рослин. 2017. № 20. С. 113-116.

20. Реєстрація зразків генофонду рослин в Україні. Генетичні ресурси рослин. 2019. № 24. С. 152.

21. Реєстрація колекції зразків генофонду рослин в Україні. Генетичні ресурси рослин. 2017. № 20. С. 133.

22. Оценка качества зерна. Справочник / сост. : И. И. Василенко, В. И. Комаров. Москва : Агропромиздат, 1987. С. 68-70.

23. Chebotar S. V., Kurakina K. 0., Khokhlov 0. M. et al. Phenotypic effects of alleles of the common wheat puroindoline genes. Cytol. Genet. 2012. Vol. 46, Iss. 4. P. 202-209. doi: 10.3103/ S0095452712040056

24. Чеботар Г. 0., Чеботар С. В., Топораш М. К. та ін. Характеристика сортів пшениці селекції Полтавської державної аграр- ної академії за допомогою маркерів до генів, що визначають важливі господарсько-агрономічні ознаки. Вісн. Укр. тов ва генетиків і селекціонерів. 2017. Т. 15, № 2. С. 187-195. doi: 10.7124/visnyk.utgis.15.2.878

25. Gautier M. F., Aleman M. E., Guirao A. T. aestivum puroindolines, two basic cystine-rich seeds protein: cDNA sequence analysis and developmental gene expression. Plant Mol. Biol. 1994. Vol. 25, Iss. 1. P. 43-57. doi: 10.1007/BF00024197

26. Klčová L., Mikulikova D., Masar Š., Žofajova A. Evaluation of Slovak winter wheat quality in terms of puroindoline genes. Agriculture (Pol'nohospodárstvo). 2015. Vol. 61, Iss. 3. P. 88-96. doi: 10.1515/agri-2015-0014

27. Giroux M. J., Morris C. F. A glycine to serine change in puroindoline $b$ is associated with wheat grain hardness and low levels of starch-surface friabilin. Theor. Appl. Genet. 1997. Vol. 95. P. 857-864. doi: 10.1007/s001220050636

28 Маниатис Т., Фрич Э., Сэмбрук Дж. Методы генетической инженерии. Молекулярное клонирование. Москва : Мир, 1984. $480 \mathrm{c}$.

\section{УДК 633.11.1:577.21:664.681.15}

Леонов О. Ю., Шарипіна Я. Ю., Усова 3. В., Суворова К. Ю., Сахно Т. В. Алельний склад генів пуроіндолінів та кондитерські властивості борошна зразків пшениці м'якої озимої. Plant Varieties Studying and Protection. 2020. T. 16, № 2. C. 217-225. https://doi.org/10.21498/2518-1017.16.2.2020.209258

Інститут рослинництва ім. В. Я. Юр'єва НАAH, пр-т Московський, 142, Харків, 61060, Україна, е-таil: уитіеv1908@gтаil.com

Мета. Ідентифікувати за алельним станом гени Pina-D1 і Pinb-D1 сортів та ліній пшениці м'якої озимої селекції Інституту рослинництва ім. В. Я. Юр'єва НААН для цільового використання в селекції на високі кондитерські показники борошна. Методи. Алельний стан генів Pina-D1 i Pinb-D1 ідентифікували методом полімеразної ланцюгової реакції (ПЛР) $з$ використанням алель-специфічних пар праймерів. Кондитерські властивості борошна оцінювали, визначивши показники якості: водопоглинальну здатність борошна (ВП3), пробне випікання печива та оцінювання його якості. Результати. За результатами ПЛР-аналізу 9 зразків мали алельний склад генів пуроіндолінів (Pina-D1a і Pinb-D1a), характерний для м'якозерних сортів. Кращим за кондитерськими властивостями було борошно ліній 'L137-26-0-2', 'L137-26-0-3', воно мало показник ВП3 менший 55\%, діаметр печива 85 мм, висоту - 10 мм, оцінку поверхні 7-9 балів, що відповідало вимогам до м'якозерних пшениць. 76\% зразків належали до твердозерних сортів та мали відповідні алелі генів Pina-D1 або Pinb-D1. у дослі- дженій вибірці ген Pina-D1 був представлений 2 алелями: Pina-D1a та Pina-D1b. 27 зразків мали алель Pina-D1a, що також дозволило використовувати їх в селекційних програмах на якість зерна при схрещуванні зі зразками типу soft, 4 - алель Pina-D1b. За геном Pinb-D1 всі твердозерні зразки мали алель Pinb-D1b, а лінія 'Еритроспермум S 4241/14' була гетерогенною Pinb-D1a/Pinb-D1b. Борошно цих зразків мало характерні для твердозерної пшениці показники якості: ВП3 68\% і більше, діаметр печива 60-72 мм, висота - 13-15 мм, оцінка поверхні - 1-4 бали. Висновки. Виконані дослідження дозволили ефективно диференціювати селекційний матеріал і передати на кваліфікаційну експертизу сорт пшениці м'якої озимої кондитерського напряму використання 'L137-26-0-3' ('Мазурок'), який має алельний склад генів пуроіндолінів (Pina-D1a $\mathrm{i}$ Pinb-D1a), характерний для м'якозерних сортів, та високі кондитерські властивості борошна.

Ключові слова: пшениця м'яка озима; сорт; лінія; гени Pina-D1 і Pinb-D1; водопоглинальна здатність; печиво.

УДК 633.11.1:577.21:664.681.15

Леонов 0. Ю., Шарыпина Я. Ю., Усова 3. В., Суворова Е. Ю., Сахно Т. В. Аллельный состав генов пуроиндолинов и кондитерские свойства муки образцов пшеницы мягкой озимой // Plant Varieties Studying and Protection. 2020. T. 16, № 2. C. 217-225. https://doi.org/10.21498/2518-1017.16.2.2020.209258

Институт растениеводства им. В. Я. Юрьева НААН Украины, пр-т Московский, 142, г. Харьков, 61060, Украина, e-mail: yuriev1908@gmail.com

Цель. Идентифицировать аллельное состояние генов Pina-D1 и Pinb-D1 сортов и линий пшеницы мягкой озимой селекции Института растениеводства им. В. Я. Юрьева НААН для целевого использования в селекции на высокие кондитерские показатели муки. Методы. Аллельное состояние генов Pina-D1 и Pinb-D1 идентифицировали методом полимеразной цепной реакции (ПЦР) с использованием аллель-специфических пар праймеров. Кондитерские свойства муки оценивали, определив показатели качества: водопоглотительную способность муки (ВПC), пробную выпечку печенья и оценку его качества.
Результаты. По результатам ПЦР-анализа 9 образцов имели аллельное состояние генов пуроиндолинов, характерное для мягкозёрных сортов - Pina-D1a и Pinb-D1a. Лучшей по кондитерским свойствам была мука линий пшеницы 'L137-26-0-2', 'L137-26-0-3', она имела показатель ВПС меньше 55\%, диаметр печенья 85 мм, высоту - 10 мм, оценка поверхности печенья составляла 7-9 балов, что соответствовало требованиям к мягкозёрным пшеницам. 76\% изученных образцов относились к твёрдозёрным сортам и имели соответствующие аллели генов Pina-D1 или Pinb-D1. В опытной выборке образцов ген 
Pina был представлен 2 аллелями: Pina D1a и Pina D1b. 27 образцов имели аллель Pina D1a, это также позволило использовать их в селекции на качество зерна при скрещивании с сортами типа soft, 4 - аллель Pina D1b. По гену Pinb все твёрдозёрные образцы имели аллель Pinb D1b, а линия 'Эритроспермум S 424-1/14' была гетерогенной Pinb D1a/Pinb D1b. Эти образцы имели соответствующие твёрдозёрным пшеницам показатели качества муки: ВПС 68\% и выше, диаметр печенья 60-72 мм, высота - 13-15 мм, оценка поверхности - 1-4 балла. Выводы. Проведен- ные исследования позволили эффективно дифференцировать селекционный материал и передать на квалификационную экспертизу сорт пшеницы мягкой озимой кондитерского направления использования 'L137-26-0-3' ('Мазурок'), который имеет аллельный состав генов пуроиндолинов (Pina-D1a и Pinb-D1a), характерный для мягкозёрных сортов, и высокие кондитерские свойства муки.

Ключевые слова: пшеница мягкая озимая; сорт; линия; гены Pina и Pinb; водопоглотительная способность; печенье.

Надійшла / Received 14.05.2020 Погоджено до друку / Accepted 10.06.2020 